\title{
myScience-Engaging the Public in U.S. Geological Survey Science
}

\section{myScience: Connecting People, Promoting Engagement}

myScience (http://txpub.usgs.gov/myscience/) is a Web application developed by the U.S. Geological Survey (USGS) Texas Water Science Center through a partnership with the USGS Community for Data Integration to address the need for increasing public awareness and participation in existing USGS citizen science projects. The myScience application contains data for 20 projects available for public participation representing all USGS mission areas. A visitor to the USGS education Web site (http://education.usgs.gov/) can click on the Citizen Science link to search for citizen science projects by topic or location, select a project of interest, and click "Get Involved.” Within the USGS, an internal version of myScience serves to build a community of practice and knowledge sharing among scientists who lead or would like to lead a crowdsourcing project.

\section{USGS Education}

USGS Education Home Primary Education

\section{Featured Topic}

\section{Citizen Science}

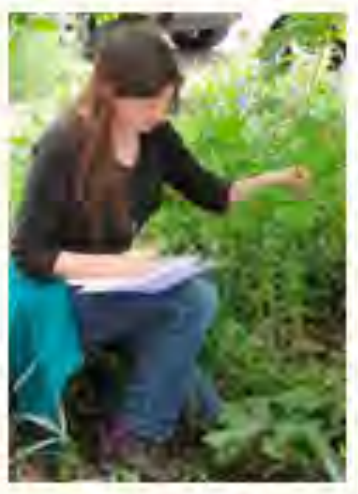

Our Education home

page now has a

permanent link to

"myScience", a

collection of USGS

citizen Science

websites. Your

students can

contribute to national

databases by

collecting information on earthquakes, landslides, volcanic ash, phenology, birds, streamflow, and crickets. This site works best in the Internet Explorer and Chrome browsers.
A broad set of research topics are positively affected by engaging the public in USGS science through the myScience application, from biodiversity and landslides to water and mapping. An example of a research topic benefitting from the participation of citizen volunteers pertains to the growing problem of invasive species, which are "nonindigenous" or not native to a particular area and capable of harming that area. Nonindigenous species often spread rapidly in new environments where their natural predators and other controls found in their original habitats are missing, often resulting in precipitous declines of native species and large economic and human health costs (Reed and Walters, 2015; U.S. Fish and Wildlife Service, 2015). The Nonindigenous Aquatic Species Online Sighting Report System is a project that is part of the myScience application and allows citizen volunteers to participate in tracking the spread of invasive aquatic species. By documenting aquatic species that are nonindigenous to the United States, citizen volunteers are helping to populate a central repository of spatially referenced and verified occurrences of such species through the project search portal on the myScience Web page. Databases specific to different invasive aquatic species are being populated, such as the sighting database for the highly invasive Dreissena polymorpha (zebra mussel), which has spread to several lakes in north Texas since the first confirmed sighting of zebra mussels in the State in 2009 (Churchill and Baldys, 2012).

\section{Citizen Volunteers and U.S. Geological Survey Science: Overview and Benefits}

Citizen volunteers first participated in data-collection programs of the USGS more than 120 years ago and continue to make valuable contributions to a wide range of scientific topics. For example, citizen volunteers documented streamflow-gage height as far back as the late 1800s. Citizen volunteers from the North American Bird Phenology Program produced 6 million hard copy records (paper cards) documenting bird sightings from 1880 to 1970, and as of August 2015, a worldwide, crowdsourced network of volunteers has transcribed more than 1 million of these paper cards.

The use of paper cards by citizen volunteers and professional scientists to record observations of plants and animals and other types of environmental data has largely been supplanted by programs such as Nature's Notebook, an online plant and animal phenology monitoring program that partners with many private organizations and Federal agencies including the USGS (National Phenology Network, 2015). Since 2009 when the Nature's Notebook Web site for collecting data was launched, active observers have contributed approximately 5 million records at more than 15,000 sites across the Nation, 
helping generate long-term datasets for use in scientific studies. Compared to observation networks populated with data compiled during traditional scientific studies done by either a single scientist or small group of scientists, citizen science and crowdsourcing efforts enable a higher resolution observation network reaching more areas over longer time periods while lowering costs and promoting science, technology, and math education.

To learn more about the myScience citizen science project application and explore opportunities for participating in USGS scientific research, visit http://txpub.usgs.gov/myscience/.

\section{References}

Churchill, C.J., and Baldys, Stanley III, 2012, USGS zebra mussel monitoring program for north Texas: U.S. Geological Survey Fact Sheet 2012-3077, accessed August 18, 2015, at http://pubs.usgs.gov/fs/2012/3077/.

National Phenology Network, 2015, Data dashboard: Accessed August 19, 2015, at https://www.usanpn.org/data/dashboard.
Reed, R.N., and Walters, K.D., 2015, Research and management tools for controlling invasive species: U.S. Geological Survey Fact Sheet 2014-3076, accessed September 9, 2015, at http://pubs.usgs.gov/fs/2014/3076/pdf/fs2014-3076.pdf.

U.S. Fish and Wildlife Service, 2015, Invasive SpeciesFrequently asked questions about invasive species: Accessed September 6, 2015, at http://www.fws.gov/invasives/faq.html.

- Sally Holl

\section{For additional information contact:}

Director, Texas Water Science Center

U.S. Geological Survey

1505 Ferguson Lane

Austin, Texas 78754-4501

http://tx.usgs.gov/

\section{Publishing support provided by}

Lafayette Publishing Service Center

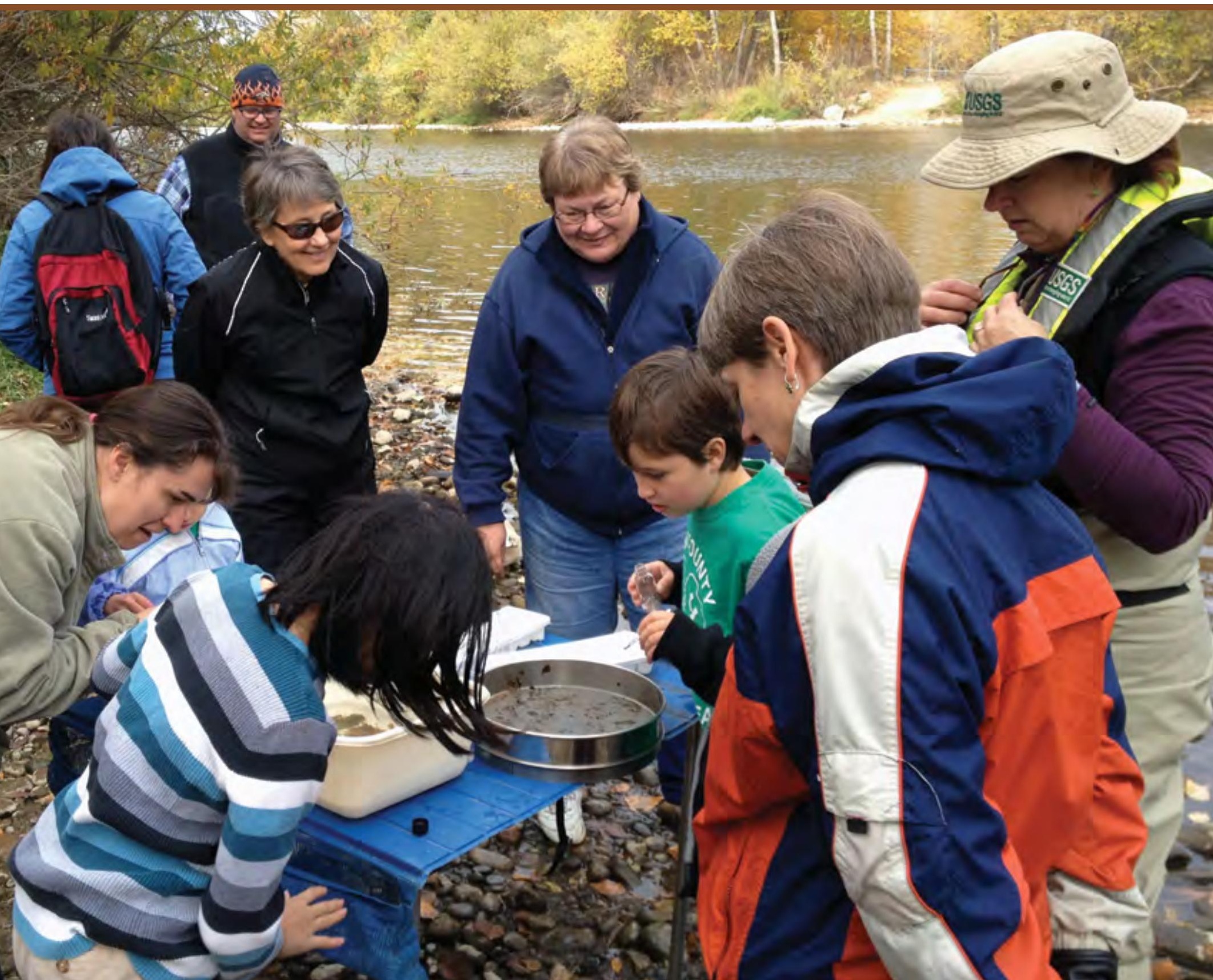

